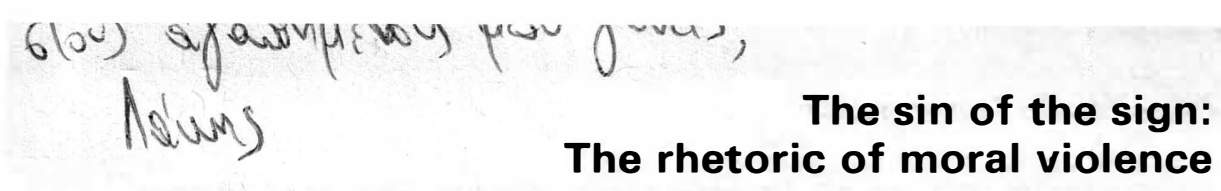

VASSILIS LAMBROPOULOS

\title{
Introduction
}

It would be hypocritical for a paper on the politics of morality to adopt an amoral attitude and assume that public standards of conduct can be discussed from a semiotic viewpoint unaffected by personal taste, inclination, and prejudice. It would also be pretentious for a rhetorical investigation of power to try and efface the figurality of its own language, insisting that it only serves the enlightened interests of its readers. Let us begin, then, by simply admitting that this rhetorical investigation of public standards of conduct (and the consequences of their violation) does not consider its political biases a sin nor its approach to the moral sign as unadulterated by violent means. The discussion that follows accepts without guilt that it consists in a series of tactical visits to texts which are commonly perceived as 'literature', 'criticism', 'sociology', and 'philosophy' in order to examine how the violent power of moral rhetoric is exercised. The deliberate transgression of genre limitations attempts not only to attend to the intertextual nature of all sign function but also to indicate the possibility of a semiotic that is more rhetorical than hermeneutic in that it views understanding as production and consumption rather than reception and use. If the sin of the sign is investigated in these pages through the signs of sin, this is clearly done in the hope that at the end its sinister power to signalize guilt will lose moral significance. In effect, this cautionary note of introduction invites you to stay tuned rather than sign off.

\section{The rhetoric of moral violence}

1. Harold Bloom, in his exposition of Kabbalistic hermeneutics as a source of inspiration for his own antithetical criticism, draws on Peirce's three classes of ideas, those of Firstness, of Secondness, and of Thirdness, 
and concludes that 'poems are truly triads, ideas of Thirdness' (Bloom 1975a: 56). He clarifies his point by commenting on a passage by Peirce: 'A sign mediates between the interpretant sign and its object. ... A Third is something which brings a First into relation to a Second ....' Bloom translates this insight into a fundamental principle of literary history: 'A poem is an idea of Thirdness, or a triadic relation, because the sign is the new poem, its object is the precursor text (however composite or imaginary), and the interpreting thought is the reading of the poem, but this reading is itself a sign' (1975a: 57).

But far more than the semiotics of intertextuality and poetic tradition, what interests Bloom is the positions available to the individual (and especially Eliot's 'individual talent') in this triadic relation, and his neurotic experience of it. This crucial difference is illuminated by another misprision of Peirce: while he asserts that 'all the cognitive faculties we know of are relative' and that 'the cognition of a relation is determined by previous cognitions', Bloom turns his attention to the semiosis of anxiety, and the above epistemological position is translated into a psychological comment: "All interpretation depends upon the antithetical relation between meanings, and not on the supposed relation between a text and its meaning' (1975: 76). This allows for a sweeping Freudian generalization: what was previously regarded only as a post-Enlightenment symptom, Poetic Influence as 'a disease of self-consciousness' (1973: 29), is now seen as a transhistorical phenomenon of the human psyche: 'The affliction of belatedness ... is a recurrent malaise of Western consciousness' (1975: 77). Suffering, it is implied, is the mode of the experience of poetry and its triadic relation: the Western man suffers from late reading, from a reading of his tradition that comes too late to give salvation from the exile into language.

It is important to emphasize the theological roots and orientation of Bloom's theory of influence which privileges guilt as the driving force behind all artistic creativity. In this context, belatedness and the ensuing despair of impotence are not simply a disease but a curse that haunts the pitiful late-comer with an ineradicable guilt. After the 'Fall of Poetic Influence' (1973:71), for the strong poet, the noble sinner of our civilization,

The curse of an increased belatedness, a dangerously self-conscious belatedness, is that creative envy becomes the ecstacy, the Sublime, of the sign-system of poetic language. (1976: 5)

Now that salvation is beyond reach, heroic damnation remains the only possible atonement: 'the belated creator achieves the uniqueness of his own consciousness through a kind of fall' (1976: 13). 
Starting with the semiosis of anxiety, Bloom moves through a psychopathology of artistic belatedness to his own 'history of interpretation', which is 'the history of revisionism and canon-formation in purely secular literary tradition' (1975a: 122-23). But revisionism is examined from the viewpoint of those condemned to revise, of those who unavoidably violate because they suffer the violence of tradition. Bloom's project is not a history of signs, an archaeology of Thirdness, but a 'genealogy of imagination', 'a study of the only guilt that matters to a poet, the guilt of indebtedness' (1973: 117) - and only of the poets who matter. In this chapter where he discusses purgation through sublimation, he considers this guilt, the cause of the anxiety of influence, as the curse befell on the individual talent for his belated appearance in the scene of writing after the departure of the gods. What is more, the guilt is affirmed and the sin of poetry is endorsed with such romantic conviction that the biblical rhetoric naturalizes the terror of tradition beyond even the reader's recognition.

Opposite to this conception of guilt-as-theodicy which tends to engulf the reader in a triadic relation of anguish and angst toward Bloom's text, stands the attempt to expose the religious presuppositions of the concept of guilt, an enterprise mounted by Nietzsche, whom the theoretician of Influence himself accepts as the 'true psychologist of this guilt' (1973: 117). Indeed, in his Genealogy of Morals Nietzsche discusses 'the fear of the ancestor and his power, the consciousness of indebtedness to him' (1967: 89), but his account is a socio-historical one. The anxiety of belatedness first developed in the 'original tribal community' as a result of the 'relationship of the present generation and its ancestors' (1967: 88). For every new generation, the burden of the past, the size of the debt, and the fear of responsibility is such that in the end the ancestor must necessarily be transfigured into a god' (1967: 89). Much later, this overriding 'consciousness of being in debt' was transformed, with the advent of the Christian God, into the 'guilty feeling of indebtedness to the divinity' (1967: 90).

This description is strongly reminiscent of Bloom's notion of the precursor poet whose imposing shadow looms large over the ephebe's desperate effort to find and express himself. The relationship between successive generations described by Nietzsche in specific socio-economic terms is conceived by Bloom as a mythical gigantomachy among strong poets. But the overlooked fact that he spares no attention or respect for the weak artist is not the most frightful aspect of his literary theogony; it is rather the curse of guilt it inflicts upon all poets that gives to his readings their authoritarian power and to his ideas their presumptuous Firstness. Bloom's criticism practices what Nietzsche means when he talks 


\section{Vassilis Lambropoulos}

about the 'moralization of the concepts' guilt and duty, their being pushed back into the bad conscience' (1976: 91).

Nietzsche attributes the way man experiences guilt, the way "he stretches himself upon the contradiction "God" and "Devil", to the "will to self-tormenting' (1976: 92), 'the will of man to find himself guilty and reprehensible to a degree that can never be atoned for; his will to think himself punished without any possibility of the punishment becoming equal to the guilt; ... his will to erect an ideal ...' (1967: 93). This is not only a deconstruction of Bloomian theology but also a magisterial destruction of the romantic Sublime, which ends with a demanding question that is still very much with us: 'But have you ever asked yourselves how much the erection of every ideal has cost?' (1967: 95).

Bloom's theory of the guilty indebtedness can be seen from a Nietzschean perspective as a symptom of what he calls 'the great nausea, the will to nothingness, nihilism' (1967: 96): 'We modern men are the heirs of the conscience-vivisection and self-torture of millenia' (1967: 95). But if influence is 'a disease of self-consciousness' (Bloom); if 'bad conscience is an illness' 1967: 88); if guilt is an expression of the 'will to selfmaltreatment' (1967: 88), how did 'the consciousness of guilt, "the bad conscience", come into the world?' (1967: 62). This is where the genealogy of guilt and the semiotics of the rhetoric of violence begin.

2. Nietzsche's relevant discussion in the Second Essay of the Genealog $y$ is part of his critique of moral values. He argues that the major moral concept Schuld [guilt] has its origin in the very material concept Schulden [debts]' (1967: 62) and traces it back to the 'contractual relationship between creditor and debtor' (1967: 63). This relationship was, of course, defined, guaranteed, and guarded by the institution of law that provided imperative guidelines about what is just and consequently what is forbidden. The experience of guilt, therefore, is directly connected with the transgression of the law, the deviant interpretation of the legal sign, which breaks the established rules of traffic and trade. 'It was in this sphere then, the sphere of legal obligations', Nietzsche concludes, 'that the moral conceptual world of "guilt", "conscience" "duty", "sacredness of duty" had its origin' (1967: 65).

The rhetoric of moral violence was first exercised through the discourse of law, its language of prohibition and exclusion - an absolute code of obligatory behavior whose use did not allow for any interpretive freedom. This discourse was also the first nomothetical expression of a firm and coherent 'moral view of the world: the feelings of a social order or rank are projected into the universe: irremovability, law, classification and coordination' (1967a: 359). Through adherence and obedience to it, such an 
absolute system of signs eventually becomes internalized: one follows its rules automatically and tends to misunderstand its imposition as the natural order of things one has to comply with. 'A morality, a mode of living tried and proved by long experience and testing, at length enters consciousness as a law, as dominating' (1967a: 277). A critical application or a sceptical attitude are no longer possible; the violence of law is assimilated by the guilty conscience as duty and signs are identified with things.

The confrontation of the instinct for freedom with the institution of law caused the illness of bad conscience and the infection of guilt. Morality as a consequence of bad conscience is the internalization of law, the suppression of the will to freedom, the unconditional acceptance of the legal code, and the naturalization of a sign system as a set of rules of conduct. Thus innocence coincided with complete obedience and stirred the perenially unfulfilled yearning for absolution and admittance into the kingdom of law. This process of normalizing acculturation has been always greatly promoted by the eager contributions of philosophy and religion, which help justify the violence of morality. In the realm of philosophy first, Nietzsche distinguishes between 'two kinds of philosopher': those who ascertain and those who legislate (logical or moral) evaluations. 'The former try to master the world of the present or the past by concentrating and abridging the multiplicity of events through signs.

... The latter, however, are commanders' (1967a: 509-10).

The importance of Nietzsche's thought for semiotics has been grossly overlooked for ideological reasons that deserve another paper. Here, at least, we have a very interesting example of his surprisingly pertinent remarks on the politics of semiosis: what distinguishes the first kind of philosopher is the use of signs in order to structure experience in a way that is necessarily exclusive but not absolute; while the other kind legislates the correct use of signs by decree. Undoubtedly, those who belong to the former category understand that 'purposes and utilities are only signs that a will to power has become master of something less powerful and imposed upon it the character of a function; and the entire history of a "thing", an organ, a custom can in this way be a continuous sign-chain of ever new interpretations and adaptations' (1967: 77). This is exactly what Peirce meant with his 'Third': the interpretation of a sign is itself another sign added to the ever increasing chain of readings and appropriations; it is this continuous development of human understanding and communication that authority tries to stop and block violently.

Nietzsche's distinction between philosophies of validity and philosophies of closure (and their respective rhetoric) is particularly useful. 


\section{Vassilis Lambropoulos}

Philosophers who ascertain evaluations must be aware that validating a sign-system into a law is 'giving a false reality to a fiction' (1967a: 282); while those who legislate evaluations based on their conception of wrong command obedience by invoking the idea that 'the object of evil and suffering is salvation' (1967a: 164). Their point of divergence and disagreement is of a semiotic nature but it soon acquires moral significance: are there any principles for the correct use of signs? if not, following the rules is a matter of interpretation; if yes, breaking the rules is a question of transgression. In the first case, morality is seen as a system of conventions, in the second as a set of obligatory norms: ignoring the conventions expresses disagreement, violating the norms entails guilt.

The price of transgression is 'punishment as the isolation of a disturbance of equilibrium' (1967: 80). Punishment is the law's retribution for one's abortive attempt to negotiate his interpretive freedom. When the validity of the legal system comes under question and its arbitrariness as a semiotic construct is foregrounded, the restoration of equilibrium is effected by the moralization of the disturbance that charges the transgressor with guilt and necessitates his punishment. Guilt, Nietzsche argues (contra Bloom), is the supreme mode of the rhetoric of moral violence. Guilt originated with the 'internalization of man' (1967: 84): when the human instincts were interiorized and the soul was born, when the individual appeared in the scene of history as pure consciousness, when the law turned from a convention into an institution, the bad conscience of the indebtor experienced the guilt of transgression. But it was only the intervention of religion that moralized the whole question by turning transgression into evil and guilt into sin.

Nietzsche's account of the justification of the violence of morality by religion evolves around the cardinal notion of sin and is based on a distinction between Hellenism and Judaism. The Greek gods were the real carriers and originators of evil in a way that rendered it all too human as an integral part of man's life. 'For the longest time these Greeks used their gods precisely so as to ward off the "bad conscience", so as to be able to rejoice in their freedom of soul' (1967: 93). Seen as a loose transcendental semiotic system, they were the effective displacement of metaphysics in the realm of conventional wisdom and social convention as represented in the public rituals of drama and democracy: 'in those days they took upon themselves, not the punishment but, what is nobler, the guilt' (1967: 94). That, Nietzsche might have added, was the epistemological break that allowed for the birth of tragedy.

A completely different Weltanschauung was expressed by 'Judaism, whose principal deed was to associate guilt with misfortune and to reduce all guilt to guilt against God' (1967a: 110-11). This exploitation of guilt 
feelings by religion led to the introduction of sin as the fundamental mode of human existence. The social experience of indebtedness and the physiological experience of depression, combined in the repression of the will to freedom by law, were translated from the secular (guilt) to the sacred level (sin) where law was viewed as God's will. Thus the system of signs already naturalized in/by the institution of law was now sacralized in/as the Word of God. 'Sin', says Kierkegaard, ' is the only thing universally predicated of man which cannot in any way ... be affirmed of God' (1954: 252). The people of Israel were elected by God through their guilt towards Him, and it is this archetypal sin that gives them direct access to His will and benevolence. Nietzsche's conception of the Western tradition is ultimately encapsulated in this polarity: the Greek's major offer to civilization is the tragic, the Jew's sin - the destruction and the sacralization of guilt respectively. In this respect, his Genealogy of Morals should also be read as an archaeology of sin.

3. Søren Kierkegaard remains the greatest theorist of sin, transgressionas-fall, in modern times. In The Sickness unto Death (another term for the 'will to nothingness') he explored the process of the individuation of sin by Christianity. While sin in the orthodox Judaic theology remained a collective experience defining the identity of a particular nation, with Christianity, which addressed the message of the Gospel to all people, it became the beginning and the mark of every man's relation with God. 'Here Christianity begins with the doctrine of the sin, and therefore with the individual' (1954: 251). 'The category of sin is the category of the individual' (1954: 250). 'The doctrine of sin ... fixes then the qualitative distinction between God and man ...' (1954: 252). 'And therewith Christianity begins, by making every man an individual, an individual sinner' (1954: 253).

In this series of aphorisms, Kierkagaard defines succinctly the Christian ethic using his unique rhetoric of religious violence. According to this doctrine, subjectivity is the sin of the individual but also the presupposition of salvation. The advent of Christianity made every man a 'bad conscience' and confirmed his anxiety of indebtedness as guilt towards God, that is, sin. Man becomes an individual through his sins; to be an individual is to $\sin$; to $\sin$ is to commit individuality and differentiation. Man separates himself from God when he sins, yet only as a sinner can he achieve himself and find Him. Clearly, the implication is that 'the individual is a sinner, but then again that it is perfection to be the individual' (1954: 252).

With Kierkegaard's notion of individuality we are back to Bloom's idea of the individual artist, the 'strong poet' (which is just one incidence 
of the pervasive influence of 'sin' in post-structuralist theory). There is no escape from the fall of belatedness or the curse of sin: they are the necessary preconditions of salvation - art and faith respectively. Man reports to tradition or God for his individuality and is accountable for its affirmation, his great sin. At the same time, it is only the overcoming of this affirmation that helps him win the battle against time and flesh. From a semiotic viewpoint, the theology of guilt is the hermeneutics of sin: whereas guilt is the outcome of the deviant interpretation, sin is the experience of any interpretation and the consequence of the exile into signification. To misread a sign and transgress a code is to break a rule, and entails punishment; but in the Judeo-Christian context, to interpret at all and to speak after Babel is the fall into écriture, in itself damnation. Beyond the naturalization of a code as morality, this is the interiorization of a sign-system as God the Judge which follows the (leap of) faith in the violent rhetoric of religion.

The violence exercised by the operations of transcendental signifieds assumes the rhetoric of a divine judgement whose subject is the interpretive performance of every sinner, since 'the concept of judgement corresponds to the individual' (1954: 253-54). The sinner is accused for the profanity of the signifier while "God is "the Judge" because before him there is no crowd but only individuals' (1954:254). Thus sin and signification are closely linked: to signify is to sin while to 'speak in tongues' is to believe. Only when the signifier becomes identical with the signified, only when language gives itself up to the Word, only when individuality waives its right to interpret, the sin of the sign is absolved.

Kierkegaard's notion of individuality eloquently corresponds to $\mathrm{Ni}$ etzsche's 'internalization of man', and testifies to their agreement that the origin of sin lies in 'bad conscience': 'By the aid of conscience things are so arranged that the judicial report follows at once upon every fault, and that the guilty one himself must write it' (1954: 255). Kierkegaard differs from Nietzsche in that his version of theophany as judgement conceals the operations of law and the morality of teleology described with unprohibited force by Paul in his Epistle to the Romans (chapter 7).

For Paul, sin does not stem from the individual's private experience of God but from the public encounter with the law. 'Nay, I had not known sin, but by the law.' The law makes man a sinner. 'For without the law sin was dead.' The purpose of the code is to incite transgression, the function of the rules is to invite their violation. In this sense, morality is a negative code, a no-saying, an established system of prohibition that makes guilt necessary and inescapable. The encounter with the law is the secular experience of God: to obey the law is to read His Book and His Word. But man cannot read because he has been condemned to interpret and 
therefore misread, which is to sin. That is why, although the law is holy, it also incites $\sin$. The rhetoric of the law represents the Word of God as its incarnation and man's incarceration.

According to Paul, the source of sin is not internal, the guilt of individuality, but an external one, the all-encompassing existence of law. The law is the horizon of human experience and the limit of its freedom: every decision is inherently related to its prescriptions; we know the world through the law, the absolute code, God's semiosis of His Will. Man's predicament is to interpret and to sin: 'for what I would, that I do not; but what I hate, that do I.' Paul's self-negation, 'Now then it is no more I that do it, but sin that dwelleth in me', could be any late-comer's apology for his unsettled anxieties, yet he makes it very clear that sin is not part of man's weak nature but a result of his imperfect submission to law. Sin is the message that law yields to man's interpretation. But without this signsystem there would be no such message. The violence exercised by the system is that it enforces its violation, that is, makes every reading a necessary transgression. Only complete, unconditional submission could produce salvation. Man's individuality of sinful interpretation is defined and dictated by the system to be read, the Book of Law.

4. The paradigmatic description of this existential heteronomy is contained in Kafka's hermeneutic allegory 'Before the Law' (first published in 1916) in The Trial (1925: chapter 9). The hero's life is determined by the Law: he begs for admittance in vain, and stays outside hoping, although his expectations are gradually frustrated. He tries everything, omits nothing, remains totally devoted to his aim, but to no avail: before his death he is told that the door he has been waiting at was only for him, purported to stand there and signify his exclusion. Because exclusion is precisely the way he experiences the Law, and the entrance is the single signifier he cannot help thinking about, interpreting, and misreading: this is what the priest terms for $\mathrm{K}$. as 'delusion'.

For Kierkegaard, individuality is human perfection, although its practices cause sin; its anxious experience allows man to communicate directly with God. On the contrary, for Kafka, individuality is punishment itself: the hero of the allegory suffers the law as his impossible admittance and his exclusion as his own failure: he is paying for the sin of his individuality. In the beginning, he becomes aware of his guilt because of the existence of the law - invisible, impersonal, impenetrable. Then he goes to beg for permission to enter, for acceptance and salvation. Finally, he realizes that the signified concealed by the door is not the authority of the law but the sin of his self: here what Nietzsche calls the 'inernalization of man', the social infection of bad conscience, reaches its last stage: man 


\section{Vassilis Lambropoulos}

curses himself for the mistake of existence. A process of relentless metaleptical repression has truned the semiosis of political terror into the existential fear of semiosis - and trembling.

It should not be forgotten that this story is part of K.'s meeting with the priest 'In the Cathedral' - and of course that the relationship between the poor man and the doorkeeper in the narrated story reenacts theirs. The priest begins the discussion with a flat statement that sets its context: 'You are an accused man'; and later on reminds K.: 'You are held to be guilty.' The whole discussion centers around questions of signification and interpretation since the 'Legend' comes from the 'writings which preface the Law', and concerns the practices of its application. What is implicitly contested during this exchange is, among other things, interpretive authority: who has the right to explicate the signs, to assign signifieds to signifiers? Naturally, the priest claims this role exclusively for himself: he assures $\mathrm{K}$. that he has narrated the story 'in the very words of the scriptures' and whirls at him the accusation: 'You have not enough respect for the written word and you are altering the story.' It is only for him, the representative of the Court before which K. stands accused, to authenticate and authorize meaning, and therefore attribute guilt and castigate sin.

The priest does not hesitate to provide the perplexed sinner with what the commentators had to say on the story, expressing simultaneously his firm belief that 'the scriptures are unalterable.' In the same way that the hero of the allegory is deprived of admittance to the Law, K. has no direct access to those scriptures: it is only for a particular interpretive community to read and explain them. His fate is to suffer for this unavailability and be punished for his sin of interpretation. All he knows about the Court is his guilt, all he learns about the scriptures is their inaccessibility. The rhetoric of the violence exercised on his individuality is the unthinkable signified Otherness of the Law, God's Word, and the moralization of this violence produces the overwhelming depression of sin.

The closest parallel to the figure of the priest that the history of philosophy has ever offered is Jacques Derrida: although they both seemingly defend writing and the multiplicity of interpretations, their ahistorical accounts of meaning's supplementarity preserve the unassailable authority of the textuality of the law, the rhetoric of its violence. Derrida, like the priest, that 'artist of the guilty feelings' (Nietzsche), plays freely with conflicting interpretations without ever questioning the authority of the scriptures which is eventually reconstructed by their own deconstructive differance. At the end of the discussion, the priest expresses the nihilistic message of deconstruction in an epigram: 'It is not necessary to accept everything as true, one must only accept it as necessary.' The 
subject of the 'Legend' is the necessary sin, man's fall into interpretation or, in semiotic terms, the politics of the hermeneutic terror.

5. If it is Derrida's ontology of the écriture/scripture that speaks through the priest in Kafka's book, it is Paul's idea of sin that haunts K.'s bad conscience. The two of them, Kafka and Paul, are brought together in Ricoeur's essay on 'Guilt, Ethics, and Religion' (1974), that attempts to answer Nietzsche's genealogy and objectify the anxiety of debt as the experience of evil. He grounds his phenomenological analysis on a sharp distinction between sin and guilt, between the suffering of Kierkegaard and the torture of K. First, he affirms Kierkegaard's position: 'Sin is a real condition, an objective situation; I would venture to say, an ontological dimension of existence' (1974: 428). It is a stain of fault and failure, and the mark of a force that overpowers man's actions. If $\sin$ is the ultimate signified of the symbolism of stain, guilt's signifying practices are usually represented by the institution of the tribunal, the Court prosecuting $\mathrm{K}$. But public morality has transposed the operations of that institution into the internal, private domain so that they have become internalized as the tyranny of 'bad conscience'. 'Thus guilt becomes a way of putting oneself before a sort of invisible tribunal which measures the offense, pronounces the condemnation, and inflicts the punishment' (1974: 429).

At this point, Ricoeur inserts the Nietzschean analysis that conceived of sin as the interiorization of guilt by the Judeo-Christian theology, revises Kierkagaard's identification of sin with individuality, and argues that 'while sin is still a collective reality, in which a whole community is implicated, guilt tends to individualize itself' (1974: 429). For him, therefore, guilt is interiorized sin, the private experience of sin that haunts moral consciousness with the judgements of the tribunal of self-reflexivity which he calls 'scrupulosity'. With the affliction of the scrupulous conscience, 'we enter into the hell of guilt, such as Saint Paul described it: the law itself becomes a source of sin' (1974:430). For Ricoeur, the individual experience of the rhetoric of violence results in the malediction of guilt. 'Guilt has then become that irreversible misfortune described by Kafka: condemnation has become damnation' (1974: 430). The pathology, then, of the moral consciousness afflicted by guilt and trapped in the prison-house of unfulfilled obligation lies at the center of his investigation.

But according to Paul, sin is known only through and because of the law, the system of signs established by true religion. 'For we know that the law is spiritual: but I am carnal, sold under sin', he confesses. If the language of the law is violent, this is because it speaks the rhetoric of our sin. Thus it is the absolute sign that inflicts the terror of guilt. This sign 


\section{Vassilis Lambropoulos}

and its carrier, the law, are not predicated; we predicate and that is our predicament. The law predicates the conditions of our sin; the law tells us all we know about the world because it speaks sin. Sin, however, is a negative knowledge and a negative experience since we can only conceive of it as transgression, as misinterpretation.

But Ricoeur wants to break the line connecting Paul and Kierkegaard, and create with his hermeneutics the possibility of a correct interpretation. With this intent, he has to retain from Nietzsche the guilt-sin distinction which the other two thinkers ignore; with the same intent, he attempts to bring the ideas of the church and the state together and prove the superiority of religious over political discourse by introducing two notions that we have not encountered before in this discussion: evil and freedom.

While for Paul the law is the language of sin, for Ricoeur it is only its rhetoric, which causes the anxiety of guilt manifested as/in the scrupulous consciousness. The true source of sin is a very real one, evil, that is, wrong-doing. Doing wrong marks the contours of human responsibility: it must and it can be avoided, so that God's will shall not be violated, sin shall not be commited, and guilt shall not develop. Man is responsible because he is not born into sin but only chooses to practice it by doing what he knows from the law is wrong. And if there is responsibility, this is because the possibility (but not necessity) of evil affirms freedom. 'Evil has the meaning of evil because it is the work of freedom; I am the author of evil' (1974: 431).

Ricoeur discovers a close link between evil and freedom that makes them entail each other, and even makes him speak about 'my evil freedom' (1974: 431). In semiotic terms, he contends that misinterpretation proves the possibility of correct interpretation and that understanding is not the fundamental mode of existence or trope of sin, but the very locus of man's responsibility. It is the semiosis of this responsibility that can lead to sin or salvation: signification is not damnation but the exemplary exercise of freedom.

On second reflection, though, it seems paradoxical that behind the symmetrical relationship between evil and freedom that Ricoeur defines, another already familiar symmetry lurks - between law and sin - which mirrors their mutual interdependence. When he asserts that 'evil is nothing in itself; $\ldots$ it is a relation, not a thing, a relation inverted with regard to the order of preference and subordination indicated by obligation' (1974: 433), he himself points to this connection. If freedom includes evil and evil reveals freedom, then an analogy can be seen between the parallel ways in which sin includes law and law reveals sin. Individual responsibility is again judged according to its semiotic performance: 
if signification includes the transcendental signified and this reveals signification, then this is still the same rhetoric of onto-theological violence exercising its unremitting terror on interpretation.

The suspicion is confirmed when Ricoeur defines evil as 'a preference which ought not to have been' (1974:434), since it is the law that delineates (and enforces and punishes) this 'ought not' - the rules prescribing human obligation. The introduction of the notion of freedom in order to transform obligation (as defined by the law) into responsibility (as allowed for by personal choice) cannot prevent the conclusion that evil is essentially the relation of freedom to the law and therefore must be understood as the possibility of the violation of the latter. Evil is simply a reification of the necessary sin 'which makes it so that I must do evil. This contradiction is interior to my freedom' (1974: 436). Evil is the signifier and sin the signified of my compulsively interpretive freedom.

Ricoeur is unable to solve this existential contradiction which leaves man engulfed by the self-reflexive mirrors of scrupulous signification, and he eventually takes refuge in the promise of Christian hope. But the farreaching implications of the dichotomy he has established are examined from the viewpoint of political theory in that epic of the law instructing freedom about the calamities of evil, Leviathan.

6. Hobbes takes good care of the political reinforcement of Ricoeur's positions. First, he agrees that freedom is man's while the necessity of evil is God's. 'And therefore God, that seeth, and disposeth all things, seeth also that the liberty of man in doing what he will, is accompanied with the necessity of doing that which God will, and no more, nor less' (1962: 160). This point proves his initial remark: 'Liberty, and necessity are consistent' (1962: 160). The next remark concerns the freedom of human actions: people are free to do whatever they want, and the fear of law many times does not prevent them from taking a particular path. It follows that 'fear and liberty are consistent' (1962: 159). But even the application of the law can do no harm since the power of a representative authority to administer it derives again from the law itself and can cause no injustice. This is then the third remark: 'Liberty of the subject is consistent with the unlimited power of the sovereign' (1962: 161).

This series of observations leads Ricoeur's conception of the human freedom under moral obligation to its logical conclusion and effectively substitutes the absence of the biblical God, which allows for the presence and the sin of subjectivity, with the presence of the secular Kingdom, the State, which demands the absence and self-effacement of individuality: 'For in the act of our submission, consisteth both our obligation, and our liherty' (1962: 163). It is the absence of God and the presence of the 


\section{Vassilis Lambropoulos}

sovereign which allows for the emergence of the interpretive subject and its semiotic subjection.

Obedience is, of course, due to the sovereign because 'the sovereign is legislator' (1962: 199) - the maker and the guardian of law. That law through which the subject experiences its subjectivity and subjection is the civil one: 'CIVIL LAW, is to every subject, those rules, which the commonwealth hath commanded him, by word, writing, or other sufficient sign of the will, to make use of, for the distinction of right, and wrong; that is to say, of what is contrary, and what is not contrary to the rule' (1962: 198). This whole ingeniously tautological definition (the law is those rules which help distinguish what is contrary to the rules), and the use of the term 'sign' in particular, brings to mind Nietzsche's two kinds of philosophers, those who ascertain and those who command evaluations, and shares with that distinction the important assumption that we learn what is right and wrong by reading signs. It is only through the use of signs that we understand, we know the world, we obey the law - or we sin. And it is only in our capacity as interpreters of the law that we sin.

Ricoeur, though, thought that we are simultaneously the interpreters of the law and the authors of evil. This insight revises Kafka's story within a story and makes the hero of the allegory responsible for the very existence of the Law as well as $\mathrm{K}$. a member of the Court prosecuting him. Hobbes accepts this revision when he says that 'every subject is author of every act the sovereign doth' (1962: 161); he also amplifies the same point elsewhere by explaining that 'every subject is by this institution [of a commonwealth] author of all the actions, and judgements of the sovereign instituted' (1962: 136). Hobbes takes Nietzsche's genealogy of guilt as ahistorized in Ricoeur's idea of communal sin and translates it into a powerful political dogma: the subject is the author of authority and consequently the actor of his own subjection. His system of a commonwealth is the universal totalization and institutionalization of bad conscience that is also crystallized in Bloom's conception of the literary tradition.

After establishing the grounds for the individual's responsibility, Leviathan proceeds to appropriate for its purposes Paul's notion of sin as the necessary misreading of the law; 'A SIN, is not only a transgression of the law, but also any contempt for the legislator. For such contempt, is a breach of all his laws at once' (1962: 216). Sin, therefore, is not only a misprision, the wrong interpretation, but even any disrespect for the creator (like the disdain accompanying the anxiety of his influence). For this reason, in order to protect its subjects, the sovereign should not allow for private readings that tempt with contempt instead of nurturing obedience. 'For a private man, without the authority of the common- 
wealth, that is to say, without permission from the representant thereof, to interpret the law by his own spirit, is another error in the politics' (1962: 491). Along lines similar to those of Derrida's ontology of the Text or the priest's ethics of reading, Hobbes argues with another violent tautology that 'in the power of making laws, is comprehended also the power of explaining them when there is need' (1962: 491). The politics of interpretation is concealed by the (insidiously political) proposition that signification unavoidably mirrors and repeats endlessly the rhetoric of the text, that is, the rules of the law; this is the sin of interpretation and the aporia of the unquestioning submission.

Since space is lacking here, we must mention only in passing the enumeration in Leviathan of the 'four causes of spiritual darkness' (1962: 438) that can lead to a life of sin and destruction: they are the abuse of the Scriptures, 'the demonology of the heathen poets', the religion and the 'erroneous philosophy of the Greeks', and false traditions and feigned history. Carefully circumscribed here are the four major areas of semiotic contestation in western civilization where the struggle over definitive and exclusive explication is constantly being waged: the Bible, art, Greek thought, and the uses of history. Every institution acquiring power, in order to establish its interpretive authority, must define its relation to these areas of intellectual experience and appropriate their significance for the sake of its own preservation.

The last stage in Hobbes' argumentation, after he has established the notion of sin as transgression of the law, is to achieve an over-arching equation between the civil, the natural, and the sacred law, and prove that, although of a different nature, they have the same importance and power of jurisdiction over life. Since the Scriptures were made law by the authority of the commonwealth, they are an integral part of the civil law; and since the law of nature is but a material realization of the law of God - obeying the commandments of the civil sovereign is like following the rules of nature and observing the faith at the same time. The ulterior purpose of Hobbes' system is to establish obedience to law as the only viable alternative to its interpretation, which violates God's will.

The identification of the civil with the natural law supports the position: 'Obedience to God and to the civil sovereign not inconsistent, whether Christian, or infidel' (1962: 435), and completes the rules of conduct in the commonwealth. The correct way to read a rule is to obey it; and the direct way to do it is to obey the sovereign. Obedience to the civil law is the best secular expression of faith, Christian or other - a public statement which revalidates the identity between divine and state law. 'All that is NECESSARY to salvation, is contained in two virtues, faith in Christ and obedience to laws' (1962: 425). Irrespectively of what 


\section{Vassilis Lambropoulos}

the laws are, to obey is to believe; and the best exercise of individual freedom is conceived by Hobbes as that complete surrender of one's interpretive rights to the sovereign's semiotic jurisdiction, which is always rewarded with salvation.

The totalitarian order of things described in Leviathan represents a perfect form of sign canonization which uses the rhetoric of symmetry to impose the violence of equivalence on the act of interpretation. The whole scheme is based on the elementary polarity which opposes the sin of interpretation to the salvation of obedience, the scepticism of reading to the faith to the text: to exercise your freedom by reading the law is to see the law as a convention, conceive of obedience only as on interpretive option, and therefore commit the sin of transgression; to practice your faith by interiorizing the law is to see the law as natural, think of obedience as the only correct interpretation, and therefore give yourself up to atonement. It is faith-as-the-belief-in-the-signified that saves man from the curse of language and the abyss of signification. If Bloom's Satan is the 'great rhetorician' (Bloom 1976: 23) of the anxiety (and the ethics) of guilt, it is Dostoyevsky's Grand Inquisitor who is the great rhetorician of the terror (and the politics) of salvation.

7. The drama of The Brothers Karamazov centers around the twin poles of sin and salvation, but their polarity is radically undermined by Ivan's poem (in Book 5, chapter 5). While Kafka made the Court omnipresent and invisible, Dostoyevsky has its supreme representative, the Inquisitor, the sovereign of the commonwealth, address 'the Prisoner'. He tells him that interpretive freedom is the right people abhor for it entails the individual responsibility of choice. Instead, they let others interpret and prefer to obey the ideal signs they erect. Servile obedience takes the burden of freedom away and restores the happiness of ignorance; people eagerly exchange freedom with blind faith to the law for that blissful happiness. Thus the law takes interpretation, the responsibility of freedom, away from man, and in this act of supression the rhetoric of violence reaches its goal: it is internalized as self-forgetfulness, the terminal semiotic impotence. Man's inquisitive 'freedom of faith' (1958: 294), 'freedom of conscience' (1958: 298), and 'freedom of choice' (1958: 299) yields to what the Grand Interpreter as priest (Kafka) or deconstructor (Derrida) or strong poet (Bloom) calls 'necessity' - the old Adam, the guild of knowledge.

The Inquisitor preaches atonement by submission: 'Oh, we will convince them that only then will they become free when they have resigned their freedom to us and have submitted to us' (1958: 303) - 'and they will submit themselves to us gladly and cheerfully' (1958: 304). But this 
benevolent legislator who is very much aware of Paul's position that it is the law which creates sin, that sin's possibility stems from the institution of law, will allow for sin in exchange for his subjects' complete obedience: 'We shall tell them that every sin can be expiated, if committed with our permission' (1958: 304). Thus transgression is incorporated into the dominant sign-system and becomes just another function of the law; its total neutralization represents the greatest promise that the Inquisitor is able to give mankind: happiness, that is, secular salvation.

Ricoeur's faith can afford only the 'hope' of an edenic language of pure signifieds and after-life justice; but the Inquisitor's commonwealth takes the initiative to remedy the uncertain expectations of the believer by deceiving him into surrendering his responsibility to a secular paradise of transparent signs. Thus the operations of the State take it upon themselves to rectify the religious anxieties of the scrupulous conscience: 'We have corrected your great work and have based it on miracle, mystery, and authority' (1958: 301). Nothing should be understood any longer, only known through/as law, the inviolable system of norms codifying reality into a communal experience of happiness that suppresses the individual experience of violence. The absolute presence of the law not only restores the absence of God but also destroys the sign and abolishes signification.

The rhetoric of violence is the language of the transcendental signified spoken by the discourses of truth through the punitive theology of guilt. The entanglement of bad conscience in the web of signification causes the anxiety of belated misreading which only the redeeming promise of salvation, i.e., unmediated knowledge, can alleviate. Thus power is exercised as truth, as the perfect identity of sign and thing, word and object, after violence has been interiorized as sin and its rhetoric as reality. The philosopher who commands evaluations, the priest who represents the Court, the sovereign of the commonwealth, the Grand Inquisitor they acquire authority (i.e., total power) when knowledge is institutionalized as truth, when rhetoric is naturalized in symbols, and when violence is interiorized as guilt. The grace of the law tropes private guilt into public truth - the atonement provided by the modern State, whereby rights assimilate desire and render it politically acceptable and socially inactive.

But no political accommodation of desire or institutional administration of power is immune from the opposition of renewed demands which necessitate constant adjustments. Michel Foucault, the greatest genealogist of truth after Nietzsche, has investigated the modes of production of knowledge and shows that every exercise of authority is continuously involved in an epistemological warfare with its dissenters: 'Where there is power, there is resistance, and yet, or rather consequently, this resistance is never in a position of exteriority in relation to power' (1978: 95). In The 


\section{Vassilis Lambropoulos}

History of Sexuality, Foucault devises a tentative map of the operations of power which produced our understanding of sexuality, and also provides some guidelines for the study of those operations in other fields. Refusing to hypostatize power as a specific social force, he describes the 'strictly relational character of power relationships' and emphasizes that their development 'depends on a multiplicity of points of resistance' which 'are present everywhere in the power network' (1978: 95).

The main points of Foucault's argument are three. First, that there is no power that is not resisted and authority that is not contested: practices of violence clash with practices of opposition. Second, that resistance is not an absolute but a plural concept expressing not a revolutionary revolt or an existential refusal but the multitude of oppositional points in the strategic field of power relations. Finally, that, as already indicated by the wishful cooperation of the subjects in Hobbes' commonwealth and Ivan Karamazov's Spain, the exercise and the resistance of power are dependent on each other and usually mutually supportive. Foucault concludes that 'more often one is dealing with mobile and transitory points of resistance' (1978: 96) whose function is conditioned by their historical and local character.

The above description takes away from the notion of resistance any idealistic, romantic, and heroic connotations and situates it back in the realm of history where the inalienable urge of human responsibility attempts to save the rhetoricity of all understanding from knowledge, the rhetoric of institutionalized violence. It is a powerful position that no semiotic enterprise interested in signification policies and the relevant politics of its own operations can safely ignore. The examination of a sign-system necessarily leads to an analysis of the mechanisms of power responsible for its constitution and should address itself to the question: which force relations produced this code of communication? and what kind of authority and violence is exercised by the rhetoric of its effective messages? Foucault's very appropriate reminder should be permanently inscribed in the interpretive practice of semiotics: 'Relations of power are not in a position of exteriority with respect to other types of relationships ..., but are immanent in the latter' (1978: 94).

8. The study in hand started with a discussion of the semiotic aspect of the late-comer's guilt-ridden indebtedness as conceived in Bloom's anxiety of influence. This aesthetic (and aestheticist) allegory of sin that presents the artist and the semiotician as biblical hermeneuts is masterfully parodied by Pynchon in his Gravity's Rainbow in a passage that destructs its psychopathology of interpretation and deserves full quotation: 
all right, say we are supposed to be the Kabbalists out here, say that's our real Destiny, to be the scholar-magicians of the Zone, with somewhere in it a Text, to be picked to pieces, annotated, explicated, and masturbated till it's all squeezed limp of its last drop ... well we assumed - natürlich! - that this holy Text had to be the Rocket, orururumo orunene the high, rising, dead, the blazing, the great one ('orunene' is already being modified by the Zone-Herero children to 'omunene', the eldest brother) ... our Torah. What else? Its symmetries, its latencies, the cuteness of it enchanted and seduced us while the real Text persisted, somewhere else, in its darkness, our darkness ... even this far from Südwest we are not to be spared the ancient tragedy of lost messages, a curse that will never leave us (1973: 520)

Not what the priest castigated K. for, but this, Pynchon insists, is our real delusion, what we still let happen without recognizing its impact: while we 'go on blundering inside our front-brain faith in Kute Korrespondences', looking for 'Deeper Significance', trying 'to make sense out of, to find the meanest sharp sliver of truth in so much replication, so much waste' (1973: 590), the Inquisitor continues exercising his grand authority, administering sin and salvation. Our desperate effort to reach an ultimate signified and transcend the fear of the sign leaves the Court undisturbed to take disciplinary care of our guilt through the rhetorical manipulation of the signifier and the therapeutic violence of punishment.

Seeing the number is supposed to be the point. But in the game behind the game, it is not the point. ... The odds They played here belonged to the past, the past only. Their odds were never probabilities, but frequencies already observed. It's the past that makes demands here. It whispers, and reaches after, and, sneering disagreeably, gooses its victims. When They chose numbers, red, black, odd, even, what did They mean by it? What Wheel did They set in motion? (1973: 208)

This is the radical question of resistance: instead of accepting the universe of signs as the actualization of the world's natural order and refusing to suspect the forbidden knowledge, true opposition asks about the law protecting the validity of the code. The law is the institutionalized interpretation whose authority demands our freedom in exchange for merciful self-forgetfulness, the happiness guaranteed by a world of transparent signs. Most people agree to comply or admit their sinful individuality by spending a life bargaining with doorkeepers. Not so Roger Mexico 'Under the Sign of the Gross Suckling' (1973: 707).

When Pynchon's hero is invited at the party of the 'Counterforce', he manages to realize that there is a grand game played there and that his passive participation is required and expected. Amidst a confused situation whose rhetoric mixes intellectual sophistication with cultural exploitation, he translates his precarious position in the practical terms of an extreme dilemma: 
They will use us. We will help legitimize Them, though They don't need it really, it's another dividend for Them, nice but not critical ... Oh yes, isn't that exactly what They'll do. Bringing Roger now, at a less than appropriate time and place here in the bosom of the Opposition ...-in the middle of all that he has to walk (ow, fuck) right into the interesting question, which is worse: living on as Their pet, or death? ... He has to choose between his life and his death. Letting it sit for a while is no compromise but a decision to live, on Their terms ... (1973: 713).

At this critical moment, Mexico decides to fight for his life and integrity; but the game is set and the rules are 'always already' (Derrida) given: how can he survive? He makes a very pragmatic choice by employing the strategy of subversion. He has no privileged time in order to deconstruct or free space in order to overturn: he can only work his irreverent subversion of the established codes through the counterviolence of their parodied rhetoric. No revolutionary stance of heroic attitude - simply a direct rebellious response, a local act of implacable resistance, and a very pertinent one because strictly rhetorical. He defies the decorum of official language by disrupting the celebration he is attending with his obscene verbiage and by introducing disorder to the prevailing system of power enunciation. Essentially, he commits an extremely radical reading against the rhetoric of the violence he is subjected to: he is subverting its conventionality by exposing the arbitrariness of its tropes. His reaction can be seen as a dramatic enactment of Foucault's idea of resistance because it is political, local, pertinent, nonconformist, recalcitrant, and rhetorical. At the end, when it succeeds, it has nothing positive to offer as an alternative, nothing to replace the disturbed order with; in its negative force, it is sheer resistance, a joyful discursive transgression.

Perhaps it is better for this paper to stop here. Its main purpose has been to visit a series of disparate texts and locate in them various strategies whereby the violent rhetoric of power tropes bad conscience into the guilt of indebtedness and the sin of disobedience. The discussion (and the visits) could go on without end, and therefore its interruption at this point is a compromise between institutional limitations and tactical decisions, rather than the expression of some conclusion; it is also an indication of how far the person who signs this as an 'author' could go today. Tomorrow things will be different and the debate about the material constitution and the ideological nature of the sign will continue. But to that effect, it should not be easily forgotten that one of the presuppositions of the debate's continuation is that nothing said herein will go 
unquestioned or unresisted, just because of the paper's publication in Semiotica or its own rhetoric of violence -

As if all words were not pockets into which now this and now that has been put, and now many things at once! (Nietzsche 1967: 180)

\section{References}

Bloom, Harold (1973). The Anxiety of Influence. A Theory of Poetry. New York: Oxford University Press.

-(1975). A Map of Misreading. New York: Oxford University Press.

-(1975a). Kabbalah and Criticism. New York: Seabury Press.

-(1976). Poetry and Repression. Revisionism from Blake to Stevens. New Haven: Yale University Press.

Dostoyevsky, Fyodor (1958). The Brothers Karamazov [1880], trans. by David Magarshack. Harmondsworth: Penguin.

Foucault, Michel (1978). The History of Sexuality. Volume I: An Introduction [1976], trans. by Robert Hurley. New York: Random House.

Hobbes, Thomas (1962). Leviathan, or The Matter, Forme and Power of a Commonwealth Ecclesiastical and Civil [1651], Michael Oakeshott (ed.). New York: Macmillan.

Kierkegaard, Søren (1954). The sickness unto death. A Christian psychological exposition for edification and awakening [1849]. In Fear and Trembling and The Sickness unto Death, trans. by Walter Lowrie. Princeton, N.J.: Princeton University Press.

Nietzsche, Friedrich (1967). On the genealogy of morals [1887]. In On the Genealogy of Morals and Ecce Homo, trans. by Walter Kaufmann and R. J. Hollingdale. New York: Random House.

-(1976a). The Will to Power, trans. by Walter Kaufmann and R. J. Hollingdale. New York: Random House.

Pynchon, Thomas (1973). Gravity's Rainbow. New York: Viking Press.

Ricoeur, Paul (1974). Guilt, ethics, and religion. In The Conflict of Inter pretations. Essays in Hermeneutics [1969]. Evanston: Northwestern University Press.

Vassilis Lambropoulos (b. 1953) is Assistant Professor of Modern Greek at the Ohio State University. His principal research interests include modern Greek literature, literary theory, and pre-Socratic philosophy. His major publications are 'The violent power of knowledge: The struggle of critical discourses for domination over Cavafy's work' (1983), 'Dionysios Solomos and the fictions of criticism' (1985), and The Text and its Margins: PostStructuralist Approaches to Modern Greek Literature (with Margaret Alexiou, 1985). 